\title{
Dalí, Disney and Destino: Alchemy in Animation
}

\section{ABSTRACT}

Salvador Dalí claimed that he made his whole life "a work of alchemy.” $\mathrm{He}$ saw in alchemy the principle of metamorphosis and "the transmutation of bodies." Carl Jung recognized "imaginatio" as the key to alchemy. As Patrick Harpur suggests: "The Work takes place in a realm intermediate between mind and matter. It is a daimonic process, a 'chemical theatre' in which processes and psychic transformations interpenetrate." The alchemist does not simply work on matter, but on the self.

In Dalís "paranoiac-critical method," objects similarly seem to exist in an "intermediate realm between mind and matter"; they are animated presences, with a life of their own. The Dalínean double-image is itself a kind of alchemical magic, invoking the "transmutation of bodies."

In 1946, Dalí began work for the Walt Disney Company on a short film, Destino. This would be, he claimed, the "First Surrealist Cartoon." The appeal of animation for him may have been based in part in what Eisenstein termed "plasmaticness": the "ability to dynamically assume any form." Animation, then, may be seen as a kind of "chemical theatre." As a "realm between mind and matter," it also functioned for Dalí as a form of mundus imaginalis, in which he could engage with the "obsessing" images in his psyche.

In Destino, Dalí invoked the alchemical process as a journey to tranfiguration and psychological "rebirth." The film was not completed in his lifetime; this account is based on the original storyboards which he produced.

Keywords: Gala, surrealism, paranoiac-critical method, Jung, Eisenstein, Breton. 


\section{PART ONE: DALÍ AND ALCHEMY}

I believe in magic, and am convinced that all new efforts at cosmogony and even metaphysics should be based on magic, and should recapture the state of mind that had guided brains like those of Paracelsus and Raymond Lully. (Dalí, Secret 370)

I am a believer in magic, which in the last analysis is simply the power of materializing imagination into reality. (Dalí, "Total” 342)

In his autobiography The Secret Life .. . (1942), Salvador Dalí affirmed his belief in "magic" and explicitly linked his own work with alchemists such as Paracelsus (370). ${ }^{1}$ In his library, he had a number of books on alchemy and magic (by, for example, Giordano Bruno, Paracelsus, and Grillot de Givry) (Ruffa 193). He told Louis Pauwels that he had made his whole life "a work of alchemy" and he considered himself "a descendent of the Catalan, Ramon Llull” (a.k.a Lully) (qtd. in Lepetit 232-33). (He was presumably referring to the numerous alchemical texts supposedly written by Llull, although their authorship is now in question.) Dalí saw in alchemy the principle of metamorphosis: he claimed that-like Llull-he believed "in the transmutation of bodies" (Unspeakable 147).

In "The Second Surrealist Manifesto," André Breton made an analogy between surrealist art and alchemy, defining both as a means of liberating the imagination (174). Carl Jung saw "imaginatio" as the key to alchemy (CW 12 para.400; italics in original). ${ }^{2}$ As they stared into their heated flasks, observing the processes of chemical change, the alchemists imagined seeing "green lions, salamanders, ravens, hermaphrodites and the likes" (Irvine). This was less a process of hallucination than "active imagination," in which entities or "spirits" seemed to materialize and assume "plastic form" (Jung, CW 8 para.402). Jung argued that such "visions" could only be "projections of unconscious contents” (CW 12 para.350). As Patrick Harpur suggests: "The [alchemical] Work takes place in a realm intermediate between mind

1 The importance of alchemy in Dalís work has been largely ignored by the critics. Strangely, Finkelstein claims that Dalís Secret Life contains no references to alchemy (305).

2 In the 1920s-30s, the surrealists declared their interest in Freud; Dalí himself stated that reading The Interpretation of Dreams (1899) was "one of the capital discoveries in my life" (Secret 167). Perhaps as a result, the connections and parallels between the surrealist movement and Jung's ideas have not been sufficiently explored by critics. See however Zuch.

3 Jung saw "active imagination" as a psychological process akin to the "alchemical operation" (CW 14 para.749). The phrase was also used by Corbin, who called it the "organ" we use to perceive the mundus imaginalis (4). 
and matter. It is a daimonic process, a 'chemical theatre' in which processes and psychic transformations interpenetrate" (141). ${ }^{4}$

In Dalîs "paranoiac-critical method" which he developed in the 1930s, objects similarly exist in "a realm intermediate between mind and matter." His declared aim was to present "the images of my concrete irrationality with the most imperialistic furor of precision" ("Conquest" 265). Objects and sensory stimuli were viewed "not just as an aspect of external reality, but also as an extension of the subjective self" (Haycock 273). Dalí himself used the example of rocks near the shoreline at Cadaqués: he recalled how, as he passed them in a boat, they seemed to change into different shapes, "as though they had been phantasmal quick-change artists of stone" (Secret 305). The rocks existed for him, then, as animated presences; phantoms of the mind, which even appeared to be autonomous entities of some kind, with a life of their own (like the psychic phenomena in the alchemist's retort).

The Dalínean double-image is itself a kind of transformative, "alchemical" magic: it invokes the process of transmutation, and invites the spectator's imaginative involvement in it. This is evident in the 1937 work, Metamorphosis of Narcissus. The sleeping or dying figure of Narcissus, on the left of the painting, seems to be carved out of rock (and may indeed have been based on rock formations around Cadaqués). He is mirrored or "doubled" on the right-hand side by the form of a large hand holding an egg with a flower emerging from it. In the poem which Dalí wrote to accompany the painting, the emergence of the flower is a moment of rebirth:
...
when that head splits
when that head bursts,
it will be the flower,
the new narcissus,
Gala-my narcissus. ("Metamorphosis" 329)

The fact that, in the painting, the egg mirrors the head, suggests that the "vision" may be the dream of the sleeping or dying Narcissus. But the work is also an image of alchemical transformation. The egg, as Bruce Elder notes, "is so common an alchemical image that there is a name for it, the ovum philosophicum, or philosophical egg" (318). It alludes in part to the alchemist's sealed retort, where the chemical reactions took place. Marie-Louise von Franz notes that the philosopher's egg symbolizes death and rebirth, and

4 Theatrum Chemicum was the title of a compendium of alchemical writings, published in six volumes, 1602-61. 
also the promise of a new life, or the regeneration of self (Patterns 12). In the case of Dalî's Narcissus, his head may be seen as the "egg/retort" in which psychological processes are leading to the "rebirth" of self.

At the end of the poem, Dalí identifies the "new narcissus" with his wife Gala. Edward James has argued that this spousal tribute was "graceful" but "out of place in the context and dragged in "par quatre épingles"” (qtd. in Lomas 184). It is significant, however, that Dalí refers to Gala as "my narcissus." The flower, in this sense, is bis creation; it has arisen from his psyche (as in a dream). At the same time, he is a kind of "alchemist," causing this transformation to occur within the "intermediate" realm of art.

Dalí met Gala (real name Elena Ivanovna Diakonova) in 1929.5 In Secret Life ..., he set out his belief, "so deeply rooted in my mind" (43), that he "was really always in love with the same unique, obsessing feminine image, which merely multiplied itself and successively assumed different aspects" (118)—sometimes real, sometimes imaginary. This began in childhood, with an image he saw in an optical toy (perhaps a praxinoscope), of a Russian girl riding in a troika. The fact that she was an animated image made her always-already a form of phantom or dream-figure. Dalí claimed that, even then, he dubbed the little Russian girl "Gala" (Secret 41), as if this event was a precognition of meeting the real-life Gala. There is an implication that he perceived the experience as an encounter with a kind of psychic "daimon" (Smith 162), almost a "goddess" (like Sophia or Psyche).

Dali's claim that he was obsessed by the same feminine image implies that she was an "anima" figure; at once a projection of his own psyche, and yet also a seemingly autonomous entity that manifested itself in different forms. In the months before he met the real Gala, Dalí said he felt that something was coming, as if their meeting was destined. He recalled that, at this time, he was in a state of nervous collapse; but she was able to "communicate immediately with my most secret self"; she "brought me back to the light through the love she gave me" (Unspeakable 91). This is how he described his "union" with Gala: "We are welded; time and space become a single reality" (Unspeakable 145). This implies a form of what Maslow has termed "peak experiences" (when space and time seem to be suspended, and the individual feels a unique sense of oneness with the universe).

Ian Gibson has argued that Dalí's account (in Secret Life and elsewhere) of his relationship with Gala was a form of myth-making, turning her (with hindsight) into his "preordained muse, mistress, psychotherapist

5 Gala's own creative agency and facilitation of Salvador's artistic practice has recently been recognized and documented in the exhibition "Gala Salvador Dalí. A Room of One's Own in Púbol” held at the Museu Nacional d'Art De Catalunya, Barcelona (2018). For a more negative view of her role, see McGirk (1989). 
and wife" (407). However, as we have seen, Dalí claimed that his obsession with a "unique" feminine image began prior to meeting Gala; and it is evident that, for him, even imaginary encounters with this "image" were real events in his psyche. The "obsessing" image acted as a form of what Jung terms "psychic daimonia" (CW 18 para. 1504): an entity which seems to exist independently, in an imaginal realm between matter and spirit. The phenomenon arises (as Jung argues) from the unconscious ( $C W 18$ para. 1504); and yet it may be experienced, not as a psychological projection, but rather, as a figure "apprehended by the Imagination on a visionary plane" (Corbin 139), as if it is "a transcendent being” (Raff xii). Arguably, for Dalí, the "obsessing feminine image" (Secret 118) was just such an "apparitional Figure" (Corbin 139). It could be argued that the meeting with Gala was, for Dalí, the culmination and completion of his obsession; he needed her to personify or materialize the "Image" for him.

Male surrealists in 1920s and 1930s aspired to achieve a form of metaphysical fusion with the "feminine, magical" Other (Bauduin 155). Love was seen as a quasi-sacred quest for a "limit-point," "an intensity of apotheosis" (Gifford 173) and transcendence. Diane Long Hoeveler has suggested that such a merging was doomed to failure; ultimately, the inherent tensions and contradictions "explode the ideal and reveal the impossibility of the task" (22). ${ }^{6}$ Arguably, however, in Dali's case, the "ideal" was realized more through art than in reality; with the art work as a kind of alchemical theatre of the imagination, a mundus imaginalis, in which artist could repeatedly re-enact the desired state, in an unending cycle of solutio and coagulatio (to use alchemical terms): the dissolution and union of Self and Other.

\section{PART TWO: DALÍ AND DISNEY}

In 1946, it was announced that Dalí would work for the Walt Disney Company on a short film, Destino. This would be, Dalí claimed, the "First Surrealist Cartoon" (qtd. in Nicolaou). He regarded Walt Disney as one of the great cinematic surrealists (along with Harpo Marx and Cecil B. DeMille); he particularly admired the Silly Symphony cartoons (produced in 1930s) as "dazzling cataclysmic rainbows," which the viewer experiences as a dream ("Surrealism" 154-55).?

${ }^{6}$ Hoeveler is referring here to the Romantic poets, but her argument can be applied equally to the surrealist vision of union with the Other.

7 The story of the collaboration between Dalí and Disney, and the historical context behind the project, are beyond the scope of this article. For an overview, see Bossert. For possible reasons why the project was aborted, see Canemaker (200). 
The appeal of animation for Dalí may have been based in part in what Eisenstein termed "plasmaticness" (21). Eisenstein admired the "spontaneity of becoming" (qtd. in Jach 82) in Disney cartoons: the rejection of fixed form, the "freedom from ossification, the ability to dynamically assume any form" (Eisenstein 21). He termed this "plasmatic" (41) because it was comparable to protoplasm, which does not possess a "stable" form but can assume "any form ... along the rungs of the evolutionary ladder" (21). He saw, moreover, that the natural "flow of the subconscious" was "plasmatic," involving the "projection of a protoplasmic condition onto consciousness" (qtd. in Jach 81; italics in original). Animation, then, may be seen as a "realm between mind and matter"; a kind of "chemical theatre" in which "processes and psychic transformations interpenetrate" (Harpur 141). In this sense, it is an "alchemical" art form; and the animator's role is analogous to the alchemist's.

As we will see, Destino invokes the alchemical process of transformation and "rebirth," culminating in the coniunctio oppositorum, the merging of Self and Other. The story follows one man's quest to fulfill his "destiny" and be united with an "obsessing feminine image" (Dalí, Secret 118). The starting point for the project was a popular song with the same title, performed by Mexican singer Dora Luz; the plan was that it would feature on the film's soundtrack. ${ }^{8}$ The lyrics evoke the very idea of love as "destiny":

... you came along

Out of a dream I recall

Yes you came along

To answer my call

I know now

That you are my destino

We'll be as one for we know

Our destiny of love. (Dominguez)

According to Christoper Jones, when Dali heard the word "destino," it sent him "into raptures, and he began creating wild, imaginative pictures to illustrate his emotions" (qtd. in King 88).

Over several months, Dalí worked with Disney animator John Hench on plans for the film. They generated a number of different story treatments

8 Dora Luz had previously appeared in a segment in the Disney "package" film, The Three Caballeros (1944), singing "You Belong to My Heart." The sequence combined live action with animation (with shots of Luz's face as she sang). Destino was intended to form part of a similar "package" film. See Canemaker (200-01). 
and storyboards. Ultimately, however, the project was aborted by Disney himself (for reasons that remain unclear); ${ }^{9}$ only a few seconds of trial footage were shot (Hench, interview by Nicolaou). In 2003, a version of the film was finally produced. The director, Dominique Monféry, worked from the Dalí/Hench storyboards, but introduced significant cuts and changes in order (he admitted) to make the film "more readable" to audiences on a narrative level (Hench, interview by Nicolaou). The following account is based on the original storyboards; they provide the most accurate record we have of the film as Dalí conceived it. ${ }^{10}$

The first image in the storyboards is a tall pyramid with a narrow base, standing on a barren plain. The pyramid features a relief of a male figure, described in a story treatment as "an unknown, a mystery, a statue without features" (qtd. in Nicolaou). The figure is covered in cracks, like an ancient ruin, and resembles Dalîs Narcissus (with the head again shaped like an egg). It is as if this, too, is a man in a state of petrified, "Atavistic Hibernation" (Dalí, Tragic 136), slowly crumbling to nothingness. Significantly, the pyramid, with its narrow base, is shaped like a metronome. The man has one arm raised, his hand pointing to the apex, so it resembles the arm of a metronome. His left hand is resting on a large clock at the pyramid base. According to Hench, the figure was meant to represent Kronos, the Greek God of Time (“... we started in with Kronos. I suppose it's a pretty obvious connection with destiny" [interview by Culhane 169]). There is a paradox in the God of Time appearing to be frozen, as if perhaps awaiting his moment of "destiny" when he will be released. The Roman version of Kronos is Saturn; and in alchemy, Saturn represents the "nigredo" stage of the process: the initial period of decay and putrefaction. (In the fifteenth century alchemical text Aurora Consurgens, the nigredo stage is likened to "a bridegroom in a tomb, awaiting his bride (the lost soul)" [von Franz, Alchemy 267]. $)^{11}$

9 The production team for the 2003 film assembled complete storyboards from images in the Disney archives (see Nicolaou). There were two versions, with minor variations between them; they did not incorporate all of the images that Dalí/Hench produced. Only limited selections from the storyboards have been published (in, for example, Bossert). In preparing this article, I have been able to study them in full. (Limits on space mean that I have had to curtail or omit the description and analysis of some of the scenes.)

10 The changes which Monféry made to the storyboards turn the film into a simpler and more conventional love story. For example, the climactic "temple" sequence is reduced to a sentimental shot of the man, embracing a large "heart" on the central podium or altar, which turns into the woman in his arms. A detailed comparison of the film and storyboards is beyond the scope of this article. Unfortunately, the majority of critics who have written about Destino have been dependent on the film, rather than the storyboards. See for example Pallant (60-65).

11 The text of Aurora Consurgens has been attributed to Thomas Aquinas (von Franz, Alchemy 178-81). 
Kronos formed part of a triumvurate of Greek gods of time, along with Aion and Kairos. Kronos represented linear clock time, in antithesis to Aion who stood for "eternal time." Kairos has been defined (by Paul Tillich) as the breakthrough of "eternal time" into the present (Pauck and Pauck 73). It is a sign of "fate," an "epiphany of the radical change, the revolution and the transition beyond" (Baert 194). Crucially, it is also an alchemical term for the moment when the stars align (so to speak), to create the right moment for change to occur (von Franz, Alchemy 44). As we will see, there are a number of key moments in Destino when there is a shift from clock time (Kronos) to Kairos. These moments are signalled by a Dalínean double image; the change of image indicates a leap or change in time, as well as a physical and psychological transformation.

After the opening image of the pyramid, there is a sudden switch to a night-time scene. A sphere which was on the apex of the pyramid sprouts spider-like legs and scurries away. Other night-time creatures appear: the clock itself morphs into three candle-worms, each with a flickering flame for a head and a wriggling snake-like tail. Matter, it seems, is now "plasmatic" (Eisenstein 41). The figure of the man disappears, and a woman appears, walking forward in the pathway, dressed in white. At this point she appears phantom-like (or like a flickering figure on a praxinoscope, perhaps). She wears a translucent dress, with a flowing trail; it resembles a transparent membrane wrapped around her, making her seem chrysalis-like, as if this is a moment of birth (as well as making her seem like another nightcreature). She glows white in the moonlight, linking her to the moon. There is an apparent reference here to alchemical symbolism, the moon or Luna representing the "female" principle. (Jung suggested that the moon represents a "white" state of innocence, the albedo stage in alchemy, "which like the moon and a bride awaits the bridegroom" [CW 14 para.155].) The change from pyramid to night-time scene, then, signifies an alchemical transformation, from solar to lunar; and also from conscious to unconscious, light to dark. There is a disruption of Kronos/linear time, with the implication of a shift to dreamtime, or onto a "visionary plane" (Corbin 139).

The change also makes it seem as if the woman is emerging from within the man; as if these events are happening in his dream. She is an anima figure in this sense; but also "apparitional" (Corbin 139) or even "theophanic." She seems to have a magical power: she is the "mercurial" spirit of flux, able to morph into different shapes and forms, but also, to cause change in others. The night-time creatures that surround her could be seen as her creatures, as if she has released them, or they are even created by her.

After the switch to the night-scene, there follows another moment of Kairos, marked again by a Dalínean double image. The woman throws 
up both of her arms in the air. (Erich Neumann has identified this kind of pose, with arms upstretched, as "the posture of epiphany" [116].) Two faces appear in profile on either side of her: a man on one side, a woman on the other; the "anima" figure forms the negative space between them. (The image is evidently based on the well-known figure-ground image of "Rubin's Vase," produced by Edgar John Rubin in 1915, which was designed to be read in two ways: either as a chalice, or as two human faces in silhouette which seem poised to kiss.) The woman's pose-her hands in the air-suggests that she has conjured up these figures by magic. The double-image marks a leap or "jump-cut" in time, but also, a magical transformation. It becomes clear that the woman on the left is, in fact, the same woman: she has left behind her orginal "chrysalis" state and become, now, recognizably human.

In one of the story treatments, the film was described as a "girl's search for destiny, to find her true love" (qtd. in Nicolaou). The film in fact has a two-part structure (in the storyboard version): the first part focuses on the woman, and the second part on the man. As noted, the "Destino" song would have been heard on the film's soundtrack. This would have made it seem as if it is was the heroine's personal anthem, with the lyrics ("I know now / that you are my destino / We'll be as one ...") implying that this is the purpose of her being: to seek union with the Other. Dalí/Hench noted that, to achieve "the working out" of her destiny, she first faces a "series of symbolic experiences which are revealed as temporary seductions and not her true destiny" (qtd. in Bossert 66). The meeting with the man is the first: she stares intently at him, and it seems that a romantic encounter is about to ensue. However, his face starts to dissolve, until all that remains is a hollow shell. She turns away from him, and begins to ascend a helicline around the outside of a tower, described by Dalí/Hench as a decadent "Tower of Babel" (qtd. in Bossert 71). Having assumed mortal form, the woman now encounters only the false "seductions" of material pleasures, and the decay of matter. The men she meets are hollow and machine-like; for example, she passes two frozen figures, holding out champagne glasses to her, as if inviting her to drink; their innards are hollow, exposing champagne bottles in place of internal organs. They are like figures in Pompeii, caught in the folly of hedonistic pleasures at the moment of death.

At the top of the heracline, there are more "hollow men," with eyeballs for heads, who gaze at her lecherously. She takes refuge in a large conch shell. The draft script states:

But all the while, she moves closer and closer to the precipice [of the tower]. Her balance is failing - she totters, plunges into emptiness ... 
As she falls, the girl becomes detached from her old personality and travels onward in a fantastic journey through space. Finally, she reaches the limitless plane [sic] where she will meet her true destiny. (qtd. in Bossert 59)

Emerging from the shell implies a new moment of (re)birth; and with it, an escape from fate or "false" destiny.

\section{BELL/GIRL}

In one shot, as the woman descends to the ground, there is a view of the plain where the pyramid stands. Nearby, there is a campanile; and in the distance (at the horizon point), there is a domed "temple," described in one story treatment as a "Temple of Love" (qtd. in Fanés 191). As we will see, at the climax of the film, this becomes the place of final "destiny," the site of transfiguration or rebirth.

The bell in the campanile is another example of a Dalínean double image: it is shaped to resemble a girl in a dress. The same image, of a bell/ girl in a campanile, appears in other works by Dalí such as Nostalgic Echo (1935) or Landscape with a Girl Skipping Rope (1936). In Nostalgic Echo, a girl is skipping, and the rope as it passes over her head resembles the round arch of the belfry. She is mirrored by the bell/girl in the tower, which is in mid-swing - the image suggesting both a bell being rung, and a girl playing on a swing. The "ringing" of the bell may imply a form of annunciation; as if this is the vision of some transcendental entity or "angel."

This figure of the bell/girl was based on a memory from Dali's own childhood, of the campanile in his sister's school in Figueres (JosephLowery 17); and, indeed, it is surely another variant on the "obsessing feminine image" (Dalí, Secret 118), like the Russian girl in the optical toy. At the same time, the bell may be read as an image of Kairos. (Jim Fitzgerald has suggested that the sounds of bells are a "summons" and "a punctuation of the world's time" [4], projecting the listener into the time of Kairos, and announcing "the imminent possibility of change" [14].) In the shot of the plain, there is a triangulation of pyramid, tower and temple, invoking the idea of conjunction and alignment. We may see these figures as representing Kronos (pyramid/male) and Kairos (bell/ girl), with the temple as Aion (or eternal time). There is also an allusion to the alchemical process, the coniunctio oppositorum of "male" and "female" elements, with the temple as the place of transformation and unity. (The location of the temple at the vanishing point of the image implies that it is the ultimate goal of the journey or process.) 
The woman descends to the plain, and crosses to the dried-up fountain which lies directly in front of the pyramid. Sunlight appears to circle the campanile rapidly, so its shadow rotates through 180 . It is like the shadow of a gnomon on a sundial; an indication that this is a new moment of Kairos. Finally, the shadow lies across the fountain pool. It is a moment of synchronicity, like a magical sign, as if the universe is pointing the way to the woman's "destiny" and prefiguring her transfiguration. She kneels and looks at the shadow of the bell, and it seems as if she is contemplating her own shadow (or her image in a mirror). The draft script states: "she is immediately entranced by the shadow of a bell[,] which appears to her symbolic of the purity within herself: she clothes herself in this shadow" (qtd. in Bossert 59). "The girl, free of her obsessions, takes on a state of purity, unaware of the nearness of her true destiny now released by her act from the bondage of time" (qtd. in Bossert 66).

The fountain is dry and cracked like the pyramid; and yet she now dives into it as if it is water, and even "drowns" it (and is reborn). (This is a form of baptism, in the sense defined by Eliade: "a total regeneration, a new birth" [188].) The woman lies down on the ground, and "clothes herself in this shadow" (qtd. in Bossert 59); indeed, she seems to dissolve into it. When she rises, she has become the bell/girl, brought to life. She is wearing a bell-shaped dress and resembles a ballet dancer in a tutu, or a paper cutout doll. Her face is blank, like a ball. She is now less an individual, than a form of energy or light, like a phantom figure in a praxinoscope. The suggestion in the script that she has been "purified" may allude to the alchemical process of "purification, initiation, perfection" (Cowlan 17); what Jung terms the "resurrection and transformation into an incorruptible state" (CW 14 para. 727$)$.

She begins to dance, expressing, it seems, the joy of her "release." In assuming her new form, she becomes the principle of metamorphosis or "plasmaticness" (Eisenstein 21): her head and body parts now have the capacity to separate, and move around each other (also as if in a kind of dance). She seems to revel in her freedom of movement and ability to change shape; and she is able to effect change in the man. As the "Dancer," indeed, she logically needs a partner. The moment that she rises from the ground in her new form, the naked figure of the man begins to peel away from the pyramid wall, pulling himself free from sticky membranes that are holding him back, as if he is emerging from a cocoon, or birth sac. $\mathrm{He}$ becomes plasmatic, in other words, as if the hard stone has dissolved to become fluid and "soft." 12

12 For Dalís theory of "the morphological esthetics of the soft and the hard," see Secret (304). 
With every gesture, the woman "tries to wake him, draw him to her, and thus, free him from the bonds of time" (Dali/Hench qtd. in Bossert 61). (Indeed, the membranes holding him back seem to be attached to the clock at the pyramid base; in one image, Dalínean melting clocks are draped over his body, clinging to him like limpets.) He sinks to the ground, as if exhausted. At one point, the woman's head resembles the head of a dandelion flower, which then dissolves into florets, floating through the air in a spiral. The script states: "In her efforts to communicate, she sends him the effulgence of her love-the spin-drift of dandelions, wafted from her head" (qtd. in Bossert 61). The use of the dandelion-the "clock" flower-is another indication that this is a moment of Kairos. Some of the florets land on the man; he rises, and throws up his arms, as if to express the ecstasy of his "release" and (re)birth. (His movements mirror the woman's earlier dance of joy.) In this way, the woman magically brings him to life; indeed, it is as if she creates him.

A single dandelion floret floats over his head, and he watches it closely. It morphs into a hummingbird which hovers over his wrist, and uses its long beak to strike at the face of his wristwatch. The hummingbird is evidently a new form of the woman, acting on the man. The rapid beats of the bird's wings suggest the speeding-up of time; at this moment, "Time is withdrawn," and the man "sees his own destiny and himself in his hand" (Dalí/Hench qtd. in Fanés 191). There is a reference here surely to the "fate" lines in cheiromancy. There is now a close-up on the man's hand. Ants emerge from a hole in the centre of the palm, scurrying over it. ${ }^{13}$ Ants suggest decay; and the implication may be that this "newborn" being discovers that his body is already threatened with decay and death. The image now morphs: there is a close-up on the hand, and the life-lines become crevices in a hilly landscape. The ants turn into numerous cyclists, all identical, hurrying in different directions, but seeming purposeless. (They have stones strapped to their heads, like some insectile protuberance; ${ }^{14}$ they represent, surely, "the mass, the collective ... the common fund of the obscure folly of humanity" [Dalí, Secret 74].) The man himself appears in this landscape; and in the rest of the film, he journeys through it, in pursuit of the woman. It is as if the unfolds on his hand, and he is, in effect, traversing the lifelines of his own "destiny."

13 A similar image, of a man staring at his hand which is suddenly covered in ants, appears in the Dalí/Bunuel film Le Chien Andalou (1929).

14 The image of cyclists appears in other works by Dalí, such as Sentimental Colloquy (1944). 
The man now faces the woman across a crevice; he sets off, as if trying to find a way to reach her. He passes through a labyrinth of classical ruins, ${ }^{15}$ and finally emerges once more on an open plain; the woman stands opposite, with her arms streched out towards him. Dalí declared the film would end "with a baseball game ballet culminating in a magical temple of love floating in the sky" (qtd. in Hazucha 109). According to Walt Disney, Dalí saw baseball as a uniquely American form of "ballet choreography" (qtd. in Hazucha 108). In the storyboards, the man now appears dressed as a baseball player; and the man and woman perform a kind of dance around each other. (The draft script states: "Using a 'pas de deux'... the choreography is based on movements executed in a game of baseball” [qtd. in Bossert 61].) The woman's head becomes detached from her body and forms the ball for the game. Fèlix Fanés has argued that the ball here represents the "focal point" of the man's psyche (191); according to one story treatment, "Desire is completely oriented" (qtd. in Fanés 191).

At one point, the man strikes the ball with his bat. He chases after it, and there is another leap in time: the ball morphs into the woman's head$\mathrm{He}$ is finally kissing her, but she appears only as a glowing ball of light behind him, so it is as if he is merging with this "ball" of energy or spirit. In other words, the man and woman are finally becoming one. The moment marks the beginning of the end. The man now appears as if he is buried in the ground, up to the waist; so he resembles a gravestone, or statue. It seems as if, in the moment of the kiss, he is losing energy and dying, prior to his final transformation. He is mesmerized by the figure of a miniature ballerina before him. The image suggests a praxinoscope theatre: a dancing figure on stage, watched by a solitary spectator. His hand reaches forwards as if to grasp this phantom figure; but she morphs into the "ball" again; which in turn morphs into an eyeball, in close-up, filling the screen. The eye seems to open up, and become a kind of "portal"; the camera passes inside, as if entering inside the cone of the eye, and into a tunnel. The moment may suggest that we (as spectators) are passing inside the man's head, accompanying him on a psychological journey into his own psyche. As the camera passes into the "eye," what follows may be compared to the stargate sequence in Kubrick's 2001: A Space Odyssey (1968); or to the experience of looking into a kaleidoscope toy, and seeing different lights and shapes as they morph. The end of the tunnel is a wall of glass; it shatters as the camera passes through it. (There is an obvious suggestion of orgasm here.) We emerge (as viewers) in the "Temple of Love" (qtd. in

15 Dalí once described Destino as "a magical exposition of the problem of life in the labyrinth of time” (qtd. in Hazucha 106). 
Bossert 62). The film's ending recalls the climax of Dalís Narcissus poem: "Now the great mystery draws near, / the great metamorphosis is about to take place" ("Metamorphosis" 328). A giant, faceless figure rises from the ground ahead, his arms outstretched. There are membranes attached to his arms, as if holding him back to the earth; as if he is bursting free in a moment of new birth, or resurrection. The storyboard invokes a process of physical and spiritual transformation: the figure's head morphs, and takes a heart shape. It stands on an altar at the centre of the "Temple." The heart carries obvious associations with love, but it is also the man's own heart, as if this is end-point of his quest within bimself. The heart splits in two; in the gap, the shape of the pyramid appears. There is now a crossfade to a shot of the pyramid on the plain, with the figure of the man once more frozen in relief. In other words, we are back to the opening image of the film.

The film's ending recalls Dalî's description of his "union” with Gala: "We are welded; time and space become a single reality" (Unspeakable 145). There is a close-up on the man. A cavity has appeared in his left breast; in it, we can see the bell/girl. She is his heart; fixed in his breast like a bell in a campanile. The bell/heart may be compared to the flower emerging from the head/egg in Metamorphosis of Narcissus. It begins to emit rays (or it could be florets), as if this "heart" is beating; and also implying the tolling of a bell, as if marking another imminent moment of Kairos. The man is once more frozen in time, as if he has expired; however, the return to the beginning also implies that the process of rebirth and regeneration must, in time, begin again. It seems that the artist-like the alchemist-must repeat the "Great Work," in a never-ending cycle; forever creating and re-creating the union of Self and Other, through a process of solutio and coagulatio.

Throughout his life, Dalí continued to pursue the phantom of the "obsessing feminine image" (Secret 118), even after he supposedly "found" her in Gala. Destino demonstrates how the art work may function as a form of chemical theatre. It enacts the union of Self with Other, or rather, with the quasi-sacred image of the Other, which is evoked through the use of selected religious icons: the temple, the heart, the "angelic" bell/girl, etc. The process is also alchemical: for Dalí, as for the author of Aurora Consurgens, the end of the "alchemical" Great Work was to "essentiate" the image of the "beloved" (Corbin 222). Dalî"s need to return to the same "obsessing feminine image" (Secret 118), was, in fact, a form of "compulsive projection" (Hillman 16); and this, it seems, was his personal "destiny."

My thanks to Jim Fitzgerald and Sam Glenn for their help with this article. 


\section{Works CiTED}

Baert, Barbara. "Kairos Or Occasion as Paradigm in the Visual Medium: Nacbleben, Iconography, Hermeneutics." Antwerp Royal Museum Annual, 2013-2014 (Jaarboek Koninklijk Museum voor Schone Kunsten Antwerpen 2013-2014). Ed. Elsje Janssen, Lynn F. Jacobs, Valerie Herremans et al. Antwerp: Garant Uitgevers, 2016. 193-251. Print.

Bauduin, Theresa. Surrealism and the Occult: Occultism and Esotericism in the Work and Movement of André Breton. Amsterdam: Amsterdam UP; Chicago, IL: Chicago UP, 2014. Print. https://doi. org/10.1515/9789048523023

Bossert, David A. Dali and Disney: "Destino." The Story, Artwork, and Friendship Behind the Legendary Film. Glendale, CA: Disney Editions, 2015. Print.

Breton, André. "Second Surrealist Manifesto." Manifestoes of Surrealism. Trans. Helen R. Lane and Richard Seaver. Ann Arbor, MI: Ann Arbor, 1972. 117-94. Print. https://doi.org/10.3998/mpub.7558

Canemaker, John. Paper Dreams: The Art and Artists of Disney Story Boards. New York, NY: Hyperion, 1999. Print.

Corbin, Henry. Alone with the Alone: Creative Imagination in the Süfism of Ibn Arabi. Princeton, NJ: Princeton UP, 1997. Print.

Cowlan, Paul F. Splendor Solis: A Consideration. N.p.: Alembic, 2016. Print.

Dalí, Salvador. "Conquest of the Irrational." The Collected Writings of Salvador Dali. Ed. Haim Finkelstein. Cambridge: Cambridge UP, 1998. 262-72. Print.

Dalí, Salvador. "Metamorphosis of Narcissus." Trans. Francis Scarpe. The Collected Writings of Salvador Dali. Ed. Haim Finkelstein. Cambridge: Cambridge UP, 1998. 324-29. Print.

Dalí, Salvador. "Surrealism in Hollywood." Dali E Film. Ed. Matthew Gale. London: Tate, 2007. 154-55. Print.

Dalí, Salvador. The Secret Life of Salvador Dali. Trans. Haakon M. Chevalier. New York, NY: Dover, 1993. Print.

Dalí, Salvador. The Tragic Myth of Millet's Angelus: Paranoiac-Critical Interpretation. Trans. Eleanor R. Morse. St. Petersburg, FL: Salvador Dalí Museum, 1986. Print.

Dalí, Salvador. The Unspeakable Confessions of Salvador Dali, as Told to André Parinand. Trans. Harold J. Salemson. London: Quartet, 1977. Print.

Dalí, Salvador. "Total Camouflage for Total War." The Collected Writings of Salvador Dali. Ed. Haim Finkelstein. Cambridge: Cambridge UP, 1998. 339-43. Print.

Dali E Disney: A Date with Destino. Dir. Ted Nicolaou. Buena Vista Home Entertainment, 2010. Film. 
Destino. Dir. Dominique Monféry. Buena Vista Home Entertainment, 2010. Film.

Dominguez, Armando. "Lyrics to 'Destino.”" Parksandrides.co. Parks \& Rides 14 Aug. 2018. Web. 19 Jan. 2020.

Eisenstein, Sergei. Eisenstein on Disney. Trans. Alan Upchurch. Ed. Jay Leyda. Calcutta: Seagull, 1986. Print.

Elder, Bruce. Dada, Surrealism, and the Cinematic Effect. Waterloo, ON: Wilfred Laurier UP, 2013. Print.

Eliade, Mircea. Patterns in Comparative Religion. Trans. Rosemary Sheed. Lincoln, NE: U of Nebraska P/Bison, 1996. Print.

Fanés, Fèlix. "Destino." Dali E Film. Ed. Matthew Gale. London: Tate, 2007. 186-93. Print.

Finkelstein, Haim. Salvador Dali's Art and Writing 1927-1942: The Metamorphoses of Narcissus. Cambridge: Cambridge UP, 1996. Print.

Fitzgerald, Jim. The Bell, The Messenger of Transformation. King's Lynn: Guild of Pastoral Psychology, 2020. Print.

Gibson, Ian. The Shameful Life of Salvador Dali. London: Faber and Faber, 1997. Print.

Gifford, Paul. Love, Desire and Transcendence in French Literature: Deciphering Eros. Abingdon: Routledge, 2016. Print. https://doi. org/10.4324/9781315250175

Harpur, Patrick. The Philosopher's Secret Fire: A History of the Imagination. Victoria, Australia: Blue Angel Gallery, 2007. Print.

Haycock, Daniel E. Being and Perceiving. London: Manupod, 2011. Print. Hazucha, Andrew. "Salvador Dalí and the Surrealism of Baseball." Baseball/Literature/Culture: Essays, 2006-2007. Ed. Ronald E. Kates and Warren Tormey. Jefferson, NC: McFarland, 2008. 10513. Print.

Hench, John. Interview by John Culhane. Walt's People. Volume 11. Ed. Didier Ghez. Bloomington, IN: Xlibris, 2011. 152-74. Print.

Hench, John. Interview by Ted Nicolaou. Dali E Disney: A Date with Destino. Dir. Ted Nicolaou. Buena Vista Home Entertainment, 2010. Film.

Hillman, James. The Thought of the Heart and the Soul of the World. Putnam, CT: Spring, 2014. Print.

Hoeveler, Diane Long. Romantic Androgyny: The Woman Within. London: Pennsylvania State UP, 1990. Print.

Irvine, Ian J. "Alchemy and the Technique of Active Imagination." Semanticscholar.org. Semantic Scholar 2011. Web. 20 Jan. 2020.

Jach, Aleksandra, ed. Zmiennoksztattność: Eisenstein Jako Metoda/Shapeshifting: Eisenstein as Method. Łódź: Muzeum Sztuki, 2018. Print.

Joseph-Lowery, Frédérique. Dali Dance and Beyond. Flushing, NY: Godwin-Ternbach Museum, 2010. Print. 
Jung, Carl Gustav. The Collected Works, Volume 8: The Structure and Dynamics of the Psyche. Trans. R. F. C. Hull. Ed. Sir Herbert Read, Michael Fordham and Gerhard Adler. London: Routledge, 1991. Print. https://doi.org/10.1515/9781400850952

Jung, Carl Gustav. The Collected Works, Volume 12: Psychology and Alchemy. Trans. R. F. C. Hull. Ed. Sir Herbert Read, Michael Fordham and Gerhard Adler. London: Routledge and Kegan Paul, 1974. Print. https://doi.org/10.1515/9781400850877

Jung, Carl Gustav. The Collected Works, Volume 14: Mysterium Coniunctionis: An Inquiry into the Separation and Synthesis of Psychic Opposites in Alchemy. Trans. R. F. C. Hull. Ed. Sir Herbert Read, Michael Fordham and Gerhard Adler. London: Routledge and Kegan Paul, 1970. Print. https://doi.org/10.1515/9781400850853

Jung, Carl Gustav. The Collected Works, Volume 18: The Symbolic Life.

Trans. R. F. C. Hull. Ed. Sir Herbert Read, Michael Fordham and Gerhard Adler. London: Routledge and Kegan Paul, 1977. Print. https://doi.org/10.1515/9781400851010

King, Elliott H. Dali, Surrealism and Cinema. Harpenden: Kamera, 2007. Print. Lepetit, Patrick. The Esoteric Secrets of Surrealism: Origins, Magic, and Secret Societies. Rochester, VT: Inner Traditions, 2012. Print.

Lomas, David. The Haunted Self: Surrealism, Psychoanalysis, Subjectivity. New Haven, CT: Yale UP, 2000. Print.

Maslow, A. H. Religions, Values, and Peak Experiences. London: Penguin, 1964. Print.

McGirk, Tim. Wicked Lady: Salvador Dali's Muse. London: Hutchinson, 1989. Print.

Monféry, Dominique. Interview by Ted Nicolaou. Dali E Disney: A Date with Destino. Dir. Ted Nicolaou. Buena Vista Home Entertainment, 2010. Film.

Neumann, Erich. The Great Mother: An Analysis of the Archetype. Trans. Ralph Mannheim. Princeton, NJ: Princeton UP, 1955. Print.

Nicolaou, Ted, dir. Dali E Disney: A Date with Destino. Buena Vista Home Entertainment, 2010. Film.

Pallant, Chris. Demystifying Disney: A History of Disney Feature Animation. New York, NY: Continuum, 2011. Print. https://doi. org/10.5040/9781628928655

Pauck, Wilhelm, and Marion Pauck. Paul Tillich: His Life and Thought. Eugene, OR: Wipf and Stock, 2015. Print.

Raff, Jeffrey. The Wedding of Sophia: The Divine Feminine in Psychoidal Alchemy. Berwick, ME: Nicolas-Hays, 2003. Print.

Ruffa, Astrid. "Operations magiques et toute-puissance d'eros.” Salvador Dali sur les traces d'eros: Actes du colloque international de Cerisy. 
Ed. Frédérique Joseph-Lowery and Isabelle Roussel-Gillet. Geneva: Éditions notari, 2010. 193-208. Print.

Smith, Robert C. The Wounded Jung: Effects of Jung's Relationships on His Life and Work. Evanston, IL: Northwest UP, 1996. Print.

von Franz, Marie-Louise. Alchemy: An Introduction to the Symbolism and the Psychology. Toronto: Inner City, 1980. Print.

von Franz, Marie-Louise. Patterns of Creativity Mirrored in Creation Myths. Dallas, TX: Spring, 1972. Print.

Zuch, Rainer. Die Surrealisten und C. G. Jung: Studien zur Rezeption der analytischen Psychologie im Surrealismus am Beispeil von Max Ernst, Victor Brauner und Hans Arp. Weimar: VDG, 2004. Print.

David Allen (Dr.) is currently Artistic Director of Midland Actors Theatre. He was previously Senior Lecturer in Drama at the University of Wolverhampton. Published books include Stanislarski for Beginners (1999) and Performing Chekhov (1999). Recent articles include: "The Most Photographed Barn in America: Simulacra of the Sublime in American Art and Photography" (Text Matters 8) and "Being Human: Edward Bond's Theories of Drama"' (Text Matters 7), both with Dr. Agata Handley; “Seeing Double: Disney's Wilderness Lodge” (European Journal of American Culture 31.2); "Disneyland: Another Kind of Reality" (EJAC 33.1); and "A Town Called Celebration" (EJAC 35.3).

ORCID: 0000-0001-5699-5877

david@midlandactorstheatre.co.uk 